\title{
Plant Feeding Insects and Nematodes Associated with Miscanthus
}

\section{Tatyana Stefanovska, Valentina Pidlisnyuk, and Andrzej Skwiercz}

\begin{abstract}
Plant feeding insects and nematodes have the potential to impact Miscanthus growth and product yield. The biological ecosystems associated with Miscanthus include many organisms that are beneficial to Miscanthus; however, a number of pests have been identified and studied. Some plant feeding pests have importance for both Miscanthus and some food and feed crops. It is important to consider pest migration from one crop to another when fields are nearby. Miscanthus mealybugs, aphids, May beetles, nematodes, armyworms, and rootworms have been found in fields of Miscanthus. Norovirus and Tobrivirus have nematode vectors that may transmit these viruses. This chapter provides information on important plant feedings insects, nematodes, and other pests that have been found with Miscanthus and have been studied and reported in published literature.
\end{abstract}

\section{CONTENTS}

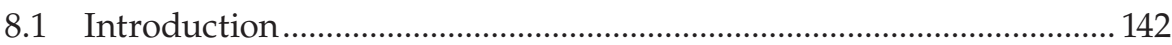

8.2 Plant Feeding Insects with Piercing-Sucking Mouth Parts ................. 143

8.2.1 Miscanthus Mealybug.............................................................. 143

8.2.1.1 Identification ........................................................... 143

8.2.1.2 Life Cycle ..................................................................... 143

8.2.1.3 Damage................................................................... 143

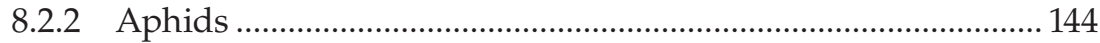

8.2.2.1 Identification ........................................................ 144

8.2.2.2 Life Cycle.................................................................. 144

8.2.2.3 Damage..................................................................... 144

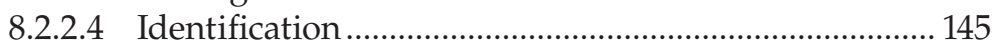

8.2.2.5 Life Cycle ................................................................. 145

8.2.2.6 Damage.................................................................. 145

8.3 Plant Feeding Insects with Chewing Mouth Parts ............................. 147

8.3.1 Generalist Coleoptera ........................................................ 147 
8.3.1.1 Identification ................................................................ 147

8.3.1.2 Life Cycle ....................................................................... 147

8.3.1.3 Damage........................................................................ 147

8.3.2 Generalist Lepidoptera............................................................... 147

8.3.2.1 Identification ................................................................ 148

8.3.2.2 Life Cycle........................................................................ 148

8.3.2.3 Damage ........................................................................ 149

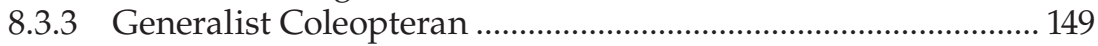

8.3.3.1 Identification ................................................................. 149

8.3.3.2 Life Cycle.................................................................... 149

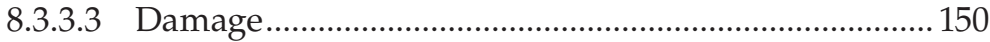

8.4 Plant Feeding Nematodes Associate with $M . \times$ giganteus...................... 150

8.4.1 PPNs - Potential Vector of Plant Viruses ..................................... 151

8.4.2 Ecto-, Endoparasites, and Hyphal/Root Feeders ........................ 151

8.4.3 The Indication of $M . \times$ giganteus Plantation State with

Plant-Feeding Nematodes ……………………………….......... 153

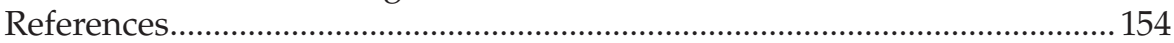

\subsection{Introduction}

Bioenergy systems aimed at replacing fossil fuels with bio-based resources contribute significantly to the shift in agricultural and marginal land use (Warner et al., 2013). The creation and/or conversion of land occupied by bioenergy systems can result in the loss of areas, currently providing additional ecosystem services (Cook, 1991; Stefanovska et al., 2015; Reid et al., 2020), including the loss of diversity of flora and fauna (Elshout et al., 2019). By reducing plant varieties in bioenergy crop plantations, insect and nematode species/functional diversity, community structure will be affected by modifying the associates' food webs (Landis \& Werling, 2010). Bioenergy crops and adjacent to them food/feed crops can be affected by this reduction (Thomson \& Hoffmann, 2011). Biofuel crops' changing may also influence the temporal and spatial distribution, and efficacy of beneficial organisms involving in pest control that would reduce or decrease the efficacy of biocontrol (Werling et al., 2011).

Miscanthus spp. produces high yield with low input (Gołąb-Bogacz et al., 2020) on agricultural as well as marginal, deteriorated, and contaminated land (Gruss et al., 2019) and determines the great socio-economic potential (Ben Fradj et al., 2020). M. x giganteus is a habitat for many insects and nematodes, which can hold beneficial and plant-feeding status (Winkler et al., 2020). This chapter will be focused on plant feeding insects and nematodes that were reported on Miscanthus plantations in Europe and USA during 
different stages of crop development with explanation of their potential to reduce the crop yield.

\subsection{Plant Feeding Insects with Piercing-Sucking Mouth Parts}

\subsubsection{Miscanthus Mealybug}

M. x giganteus parenteral plants M. sacchariflorus and M. sinensis are susceptible to several pests in native countries (Stefanovska et al., 2017a). Mealybug Miscanthiococcus miscanthi Takahashi (Hemiptera: Pseudococcidae) is a subtropical species (most often distributed within the boundaries of $23.24^{\circ}-$ $30.16^{\circ}$ Northern Latitude); however, it can be spread to higher latitudes: $44.10^{\circ}$. Several studies show that in Southeastern states of the US, Miscanthus mealybugs are becoming a significant problem (Wheeler, 2013).

\subsubsection{Identification}

The body of mealybug adult females is wingless, soft, and oval, approximately $3 \mathrm{~mm}$ long. They are covered by white wax. Male mealybugs are up to $2 \mathrm{~mm}$ long with four eyes, two wings, and long tails. Newly hatched nymphs (crawlers) are flat, oval, and yellow, and generally do not have a waxy coating. Older nymphs are covered with fluffy, white wax.

\subsubsection{Life Cycle}

Adult females and crawlers overwinter and commonly emerge by May. Adult females of most mealybugs lay 100-200 or more eggs in cottony egg sacs that are attached to crowns, leaves, or twigs. It takes about a month for crawlers to mature. Spreading of Miscanthus mealybugs generally happens via propagating infested plants or blowing of crawlers into nearby plants. This pest has three generations per year.

\subsubsection{Damage}

The species suck sap from plant phloem, causing yellowing and twisting of leaves, stunted and slowing down of plant growth. Insects also can damage plants by excreting the sticky honeydew which may be a substance for black sooty mold fungus growth. The good signs of a possible infestation of Miscanthus mealybug are purple spots on infested stems.

Because M. x giganteus is capable to form a strong root system and big vegetative mass, a thick layer of dead organic litter can serve as niche for 
warm climate mealybug M. miscanthi, and for various indigenous coccid species feeding on cereals (Kosztarab \& Kozár, 2012). Moving to the root system under the cover of organic litter Miscanthus mealybug is capable to survive at air temperature which is much lower than in its natural habitat conditions (Stefanovska et al., 2017a).

\subsubsection{Aphids}

Twenty-one aphids are known to use Miscanthus (mostly M. sinensis) as a host; therefore, there is a potential for aphid damage of the crop. Results of field study carried out by Semere and Slater (2007) demonstrated domination of family Aphidiidae among Homoptera. There still is a gap in information about broad Aphid biodiversity at Miscanthus. The extensive field surveys carried out in USA (Bradshaw et al., 2010) and laboratory studies (Pallipparambil et al., 2014) indicated that among the insects reported in Miscanthus, the yellow sugarcane aphid, Sipha flava Forbes, is a potential pest of M. x giganteus. Sipha flava (Homoptera: Aphididae) is native to North America (Hentz \& Nuessly, 2002) and has been recorded on approximately 60 plant species, including Cyperaceae, Poaceae, and Commelinaceae (Kindler \& Dalrymple, 1999).

\subsubsection{Identification}

Wingless yellow sugarcane aphids and nymphs are $1.3-2 \mathrm{~mm}$ in length bright yellow or green at the low temperature, and the insect body is tightly covered by hairs. Rows of spots are present down the top and along lateral margins of the abdomen. The spots' size and tailpipes are reduced compared to other aphid species.

\subsubsection{Life Cycle}

The species reproduce by parthenogenesis during the year in warmer climates, but sexual forms occur in regions with cold winters and it can overwinter in eggs. Development to adulthood takes $8-15$ days and is highly dependent on temperature and host plants. This pest has many generations.

\subsubsection{Damage}

The yellow sugarcane aphid causes damage to sorghum, sugarcane, and several species of lawn pasture grass (Kindler \& Dalrymple, 1999). Feeding initially results in leaves turning to yellow or red, depending on the host plant and temperature. Prolonged feeding can lead to premature senescence of leaves and plant or stalk death. Colonies or groups of sugarcane aphids are located around the midrib of the bottom side. Additionally, sugarcane aphids are prolific producers of honeydew which supports growth of sooty mold fungi. Yield reductions commonly occur due to feeding damage to early plant growth stages (Hentz \& Nuessly, 2004), resulting in chlorosis and death 
of three pairs of leaves. Besides direct damage, yellow sugarcane aphid also transmits sugarcane mosaic potyvirus (Blackman \& Eastop, 2000).

The S. flava was first recorded on M. xgiganteus in 2008 in leaf damage collected from seven locations of Indiana, Illinois, Nebraska, Kentucky, and Iowa (Bradshaw et al., 2010). Aphids were found on young to old plantings (1-21 year) in large populations. Aphids feeding leads to leaf death. The symptoms of $M$. $\times$ giganteus infestations, specifically yellowing and redding of leaves, were very similar to sugarcane (Nuessly \& Hentz, 2002) and sorghum (Costa-Arbulú et al., 2001). The S. flava damage has economic importance as a key factor of $M$. $\times$ giganteus plantation establishment during the first year of vegetation.

Corn leaf aphid Rhopalosiphum maidis L. (Homoptera: Aphidiidae) is native to Asia, although they have spread almost worldwide. It occurs sporadically in cool temperature climate (Blackman \& Eastop, 2000). In several countries it is considered as an economically important pest of Poaceae (Gramineae) monocot crops, namely, wheat, barley, sorghum, and M. sinensis (Carena \& Glogoza, 2004; Huggett et al., 1999). This damage potential is especially concerning because most plant viruses are transmitted by aphids (Hull, 2002) and R. maidis can transmit the RPV strain (cereal yellow dwarf virus) of barley yellow dwarf luteovirus (BYDV) to M. × giganteus (Huggett et al., 1999; Jarošová et al., 2013).

\subsubsection{Identification}

The wingless corn leaf aphid is oval, about $2 \mathrm{~mm}$, blue-green in color with black antennae, legs, and tailpipes. The body and legs are black. The nymphs are similar to adults with smaller size and underdeveloped antennae and tailpipes. The winged form of the aphid is about the same size as the wingless ones, with dark green to black body and black tailpipes.

\subsubsection{Life Cycle}

The species reproduce via parthenogenesis. It overwinters in both eggs and females (in warmer climates) on cereal grasses. The optimum temperature for development is around $30^{\circ} \mathrm{C}$. Corn leaf aphids live in large colonies on their host plants.

\subsubsection{Damage}

The corn leaf aphids feed by removing plant sap from the phloem. The typical signs of feeding while insect in high population are leaf mottling and/ or discoloration and reddening. The plant vulnerability to insect damage increases under drought stress. The aphids also produce honeydew, which covers the leaf surface. Mold fungi colonize the honeydew producing a black layer of fungal colonies on corn leaf surface causing the reduction of the photosynthetic leaf activity. 
Natural R. maidis infestation of M. $\times$ giganteus was found in Indiana, Illinois, Nebraska, Kentucky, and Iowa (USA) in 2008 survey. Species was observed on the young M. x giganteus whorls in first-year plantings (Bradshaw et al., 2010). The infestation of young tillers resulted in yellowing of upper leaves and occurred later compared to S. flava.

Other aphids that specialize on Poaceae family that may infest Miscanthus in countries with temperate climates and vector of pathogens are bird-cherry oat aphid Rhopalosiphum padi L., wheat aphid Schizaphis graminum Rondani, and oat aphid Sitobion avenae Fabricius. Results of 2-years' field surveys conducted in 2010-2011 in three regions: Zhytomyr, Vinnitsa, and Kyiv in Ukraine (Stefanovska et al., 2017b) found that species with piercing-sucking moth part, namely, aphids and trips were most frequently observed among 50 herbivorous species which were recorded (Figure 8.1).

Bird-cherry oat aphid was recorded as a more frequently observed pest among Aphidiidae family on 1-5-year-old plantations in all three locations in this study with low population, attacking plants of first year stands, causing yellowing of leaves.

While carrying out the survey of M. x giganteus in Lower Silesia (Poland), Hurej and Twardowski (2009) recorded R. padi, which was the dominant species among other aphids. The population was low, however, aphid attacked young plants of first year vegetation.

The field study of M. xsachariphlorus herbivores in Northern France (Coulette et al., 2013) showed that population density of bird-cherry aphid $R$. padi which is generalist was the lowest among polyphagous species, i.e., green peach aphid Myzus percicae Sulzer and bean aphid Aphis fabae Scop. Results of laboratory experiment indicated that Miscanthus is not suitable for these three aphids and even it has the potential to act as a barrier to restrict spreading of phytoviruses (Coulette et al., 2013).

A

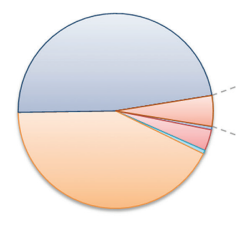

C

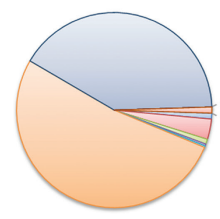

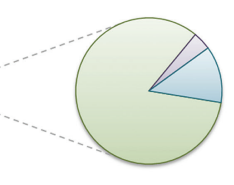

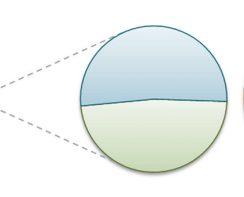

B

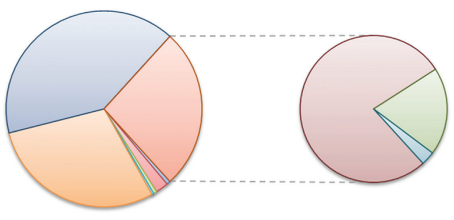

D

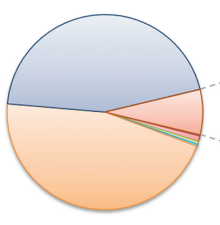

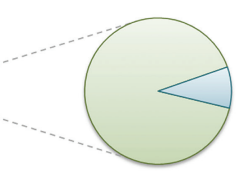

\author{
$\square$ Elateridae \\ $\square$ Chrisomelidae \\ $\square$ Scarabaeidae \\ $\square$ Gryllotalpidae \\ $\square$ Tettigoniidae \\ $\square$ Thripidae \\ $\square$ Aphidiidae \\ $\square$ Cicadellidae \\ $\square$ Miridae \\ $\square$ Cecidomyidae \\ $\square$ Noctuidae
}

FIGURE 8.1

Frequency of occurrence of herbivorous individuals by families at the investigated locations in 2010-2011 growing seasons: A - Zhytomyr, B - Vinnitsa, C - Kyiv (1), D - Kyiv (2). (Modified from Stefanovska et al., 2017b.) 


\subsection{Plant Feeding Insects with Chewing Mouth Parts}

\subsubsection{Generalist Coleoptera}

May beetle (Melolontha melolontha L.) and June beetle (Amphimallon solstitialis

L.) (Coleoptera: Scarabaeidae) are the most destructive pests of turf grasses and cause economic threat as polyphagous pest of many fields, horticulture and orchard crops, including Poaceae (Gramineae) monocot crops which Miscanthus plants belong to.

\subsubsection{Identification}

Adults of May beetle are stocky insects that vary in color: shade of brown and tan to dark chocolate with length of $22-30 \mathrm{~mm}$. The larvae (grubs) - fat, C-shaped whitish yellow grubs with brown heads in length of $40-45 \mathrm{~mm}$ in final instar.

\subsubsection{Life Cycle}

May beetles develop for 3-5years. It hibernates in the stage of grubs and adults. Grubs live in the soil feeding on plant roots for several years. For pupating they move deeper in the soil, later emerging from the ground as adults in the spring.

\subsubsection{Damage}

Adult beetles eat up leaves and flowers, preferring trees. Grubs feed on dead organic matter and plant roots, resulting in visible water stress and ultimately ending in the death of the plant. The larval stages of these beetles are more harmful to crops.

M. melolontha was the dominant species observed (Stefanovska et al., 2017b) in two out of three regions in a field survey of M. xgiganteus growing in Ukraine (Figure 8.2). The reduction of M. $x$ giganteus seedlings at first year of vegetation due to feeding grubs on roots was observed in a field infected by M. melolontha $\mathrm{L}$. and A. solstitialis $\mathrm{L}$. in population density -7.2 grubs $\mathrm{m}^{-2}$. The second and third grub instar causes the biggest damage. Preplanting treatment of rhizomes by insecticides had positive effect on seedling emergence, survival, and further plant height (Sabluk et al., 2014).

\subsubsection{Generalist Lepidoptera}

Fall armyworm Spodoptera frugiperda Smith (Lepidoptera: Noctuidae) is one of the important polyphagous pests distributed in Brazil, Argentina, USA (Clark et al., 2007; Montezano et al., 2018), and Africa (De Groote et al., 2020). 


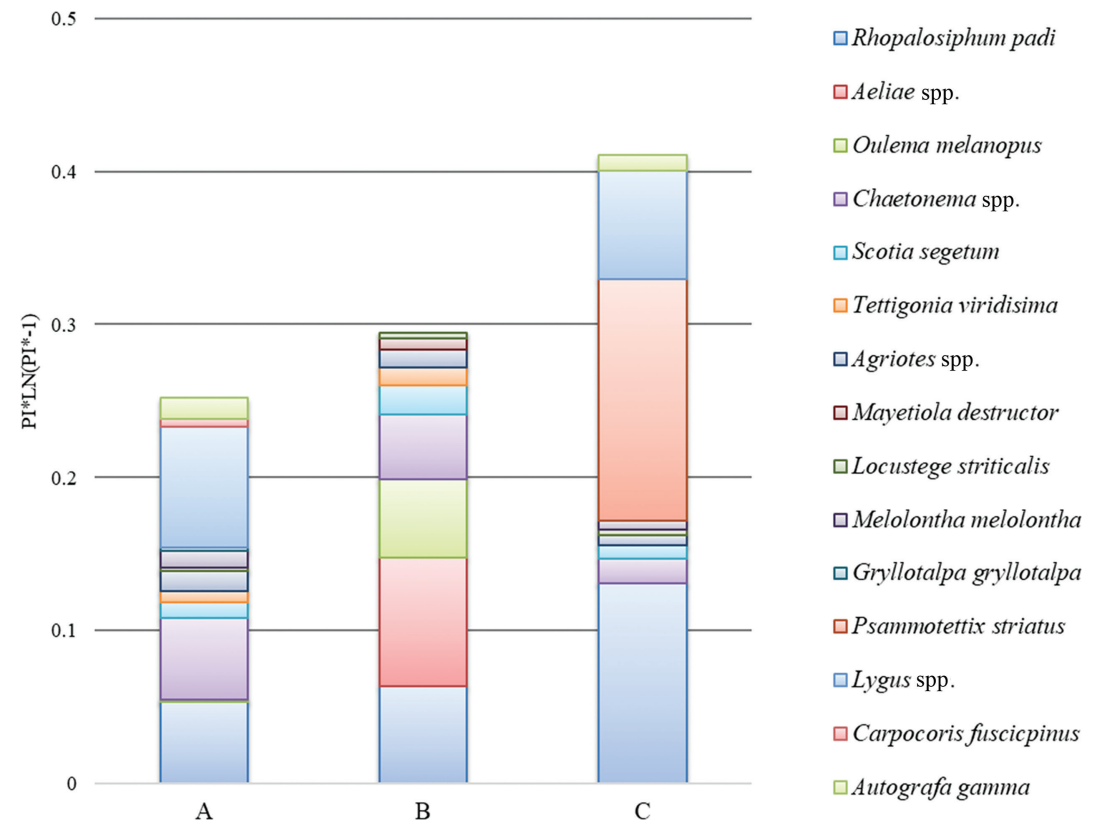

FIGURE 8.2

Variation of insect species and genera on M. x giganteus in three location of Ukraine, 2010-2011. A - Zhytomyr, B - Vinnitsa, C - Kyiv. (Modified from Stefanovska et al., 2017b.)

It caused significant yield reduction on corn, soybean, cotton, and diverse grasses; pest has two strains: rice and corn.

\subsubsection{Identification}

The moths have a wingspan of $32-40 \mathrm{~mm}$. The adult moths have a brown or gray forewing and a white hindwing. Male fall armyworms have more patterns and a distinct white spot on each forewing. The hind wing is similar for both sexes: silver white with a narrow dark border. Larvae are a light green to dark brown with longitudinal stripes. In the sixth instar, larvae can reach $4.5 \mathrm{~cm}$ long (Brambila, 2009).

\subsubsection{Life Cycle}

The Fall armyworm hibernates in the stage of pupa; however, it is not tolerant to low temperature and can survive only in mild winters and when freezing occurs all stages are usually killed. Adults can migrate over $500 \mathrm{~km}$. They lay eggs on the leaves of the host. Young larva hatch from eggs in 1-10 days and migrate to the whorl. The duration of life cycle depends on the season and in winter is longer-lasting. The number of generations is two (northern regions) and up to six (tropics). 


\subsubsection{Damage}

Larvae cause damage on the leaves when they hatch by consuming foliage. Young larvae initially consume leaf tissue from one side, leaving the opposite epidermal layer intact. The older larvae begin to make holes in leaves and eat from the edge of the leaves inward. Feeding in the whorl of corn often produces a characteristic row of perforations in the leaves.

Fall armyworm S. frugiperda was found to infest the whorls of M. x giganteus in field plots (Prasifka et al., 2009). Greenhouse study using fall armyworm population collected in the field from natural infestation indicated that both corn and rice strains of $S$. frugiperda are able to develop and reproduce on Miscanthus along with other hosts, including corn. In this experiment fall armyworm evidently preferred corn to Miscanthus; however, relative survival of rice strain fall armyworm was greater on Miscanthus. Thus, this dangerous pest can infest the biomass and food/feed crop (Prasifka et al., 2009).

Stefanovska et al. (2017b) observed two Noctuidae species in M. x giganteus: Turnip Moth Scotia segetum L. and Silver Y-Moth Autografa gamma L., feeding on planting at first year of vegetation (Figure 8.2); however, no conspicuous symptoms were found.

\subsubsection{Generalist Coleopteran}

The Western corn rootworm Diabrotica virgifera virgifera Le Conte is a native to North America, where it is considered as the main pest of corn (Yu et al., 2019). The pest is present in many European countries, spreading constantly year by year (Toth et al., 2020). Corn is the only crop in which high population densities can develop.

\subsubsection{Identification}

The adults, 5-6 $\mathrm{mm}$ long, are dark yellow in color and there are three black stripes on the wing covers. Newly hatched larvae are nearly colorless, but gradually turn white as they feed and get older. Mature larvae reach about $13 \mathrm{~mm}$ long, and are creamy, white with a brown head capsule.

\subsubsection{Life Cycle}

Western corn rootworms produce one generation per year (Chiang, 1973). The pest overwinters in the soil in egg stage. The larvae hatch from eggs from late spring to early summer. The larvae move around in the soil, feeding on the maize roots. Their development lasts approximately 1 month. Larvae pupate in the soil and emerge as adults in 5-10 days. Adults emerge throughout the summer period and can mate several times. Females lay eggs in small clutches near the base of corn stalks, where they remain unhatched for the winter (Gray et al., 2009). 


\subsubsection{Damage}

Pest causes damage in the stage of larvae who feed on both the leaves and the silk of the female inflorescence of corn. Larvae feeding reduced plants' ability to take water and nutrients. Initially, injured root tips are discolored or have brown lesions; after some time, primary or secondary roots can be completely pruned. Western corn rootworm produces a single generation each year (Yu et al., 2019).

Miscanthus is suitable for larval development for both European (Gloyna et al., 2011) and the US (Spencer et al., 2009) populations of the western corn rootworm. Since Western corn rootworm survives on M. x giganteus, it has economic consequence. Without crop rotation and tillage, the risk of Western corn rootworm from $M . \times$ giganteus as biomass crops into nearby food and feed crops, including corn may significantly increase. This is especially challenging in upscaling of $M . \times$ giganteus production in agricultural and marginal land in intensive monoculture systems.

\subsection{Plant Feeding Nematodes Associate with $M . \times$ giganteus}

The limited number of reported nematodes in M. xgiganteus can be explained by restricted range of researches conducted in this area. Plantfeeding nematodes according to the feeding habits are commonly assigned to the following trophic groups: obligate plant feeders, facultative plant feeders that alternatively feed on fungi or bacteria, and fungal feeders that alternatively feed on plants (Yeates et al., 1993). Plant parasitic nematodes (PPNs) are a very important group of pests because of economical aspect of ability to decrease food and feed crops (Bernard et al., 2017). This nematode group is studied most profoundly (Emery et al., 2017). Because of the relatively small portion of $M$. x giganteus plantations and short times since beginning of cultivation, this is still not clear to which extent PPNs can contribute to this crop yield loss.

In the frame of multistate parasitic nematode survey of 37 miscanthus and 48 switch grass plots across Iowa, Illinois, Georgia, Kentucky, South Dakota, and Tennessee (USA), the following PPNs were present: lesion (Pratylenchus spp.), needle (Longidorus spp.), dagger (Xiphinema spp.), lance (Hoplolaimus spp.), stunt (Tylenchorynchus spp.), spiral (Helicotylenchus spp.), and ring (Criconema spp.) (Mekete et al., 2009; Mekete et al., 2011a, b). The damage thresholds of M. x giganteus PPNs have not been reported yet. Mekete et al. (2011b) used values existing for monocotyledon hosts to compare it with recorded PPNs densities. It was found that population densities of Helicotylenchus, Xiphinema, Pratylenchus, Hoplolaimus, Tylenchorhynchus, Criconemella, and Longidorus spp. exceeded threshold value ranges reported for another monocotyledon host. 


\subsubsection{PPNs - Potential Vector of Plant Viruses}

The nematode survey associated with $M . \times$ giganteus was provided in established crop's stands of 1-10 years of age representing, consequently, eight locations and six soil types in Ukraine (out of which three were contaminated by trace elements) and nine localities covering eight soil types in Poland (Figure 8.3).

The obtained results indicated that group of plant-feeding species was represented by 53 species belonging to 22 genera and 10 families (Stefanovska et al., 2020). Comparison of population density of plant-feeding nematodes recorded in both Ukraine and Poland with the damage threshold values established by Mekete et al. (2011b) demonstrated that the populations of several PPNs, which are known as vector of plant viruses, were above the estimated damage threshold.

Two dangerous plant viruses, specifically Norovirus (NEPO) and Tobravirus (TOBRA), have nematode vectors. The only known nematode vectors of NEPO are in the genera Xiphinema and Longidorus whereas TOBRA is transmitted by Trichodorus and Paratrichodorus (Macfarlane, 2003; MacFarlane \& Neilson, 2009).

A total of ten nematode species capable of vectoring plant viruses were recorded in Ukraine and Poland in surveyed M. x giganteus plantations. Two species of the genus Longidorus: L. elongatus and L. attenuatus were observed only in Poland with a population range of 284-300 individuals per $100 \mathrm{~cm}^{3}$. They exceeded the damage level (5-25 individuals per $100 \mathrm{~cm}^{3}$ ) by 2.5-fold. Species of the genus Xiphinema were associated with $M . \times$ giganteus plantations in both countries with population densities below the estimating threshold. Nematodes of genera Xiphinema would not likely impact negatively the crop development and biomass yield in the observed plantations. These results are not inconsistent with Mekete et al. (2011b) who showed that this genus was potentially damaging for M. x giganteus. Emery et al. (2017) observed that Miscanthus is suitable to Xiphinema.

Three species of genus Trichodorus in Poland T. sparsus, T. similis, and T. viruliferus vs. one species in Ukraine T. sparsus were recorded. PPNs of genus Paratrichodorus recovered from the root zone of $M$. x giganteus were represented by two species: $P$. pachydermus and $P$. teres in both countries.

\subsubsection{Ecto-, Endoparasites, and Hyphal/Root Feeders}

Nematode species representing ectoparasites belonging to the genera Mesocriconema, Criconema, Paratylenchus, Geocenamus, Bitylenchus, Merlinius, Neodolichorhynchus, Sauertylenchus, Scutylenchus, and Amplimerlinius were recovered at the maximum population densities of $60-70 / 100 \mathrm{~cm}^{3}$ of soil. These values are considerably lower than in suggested damage threshold value that is estimated as 300-600 nematodes per $100 \mathrm{~cm}^{3}$. 
(a)
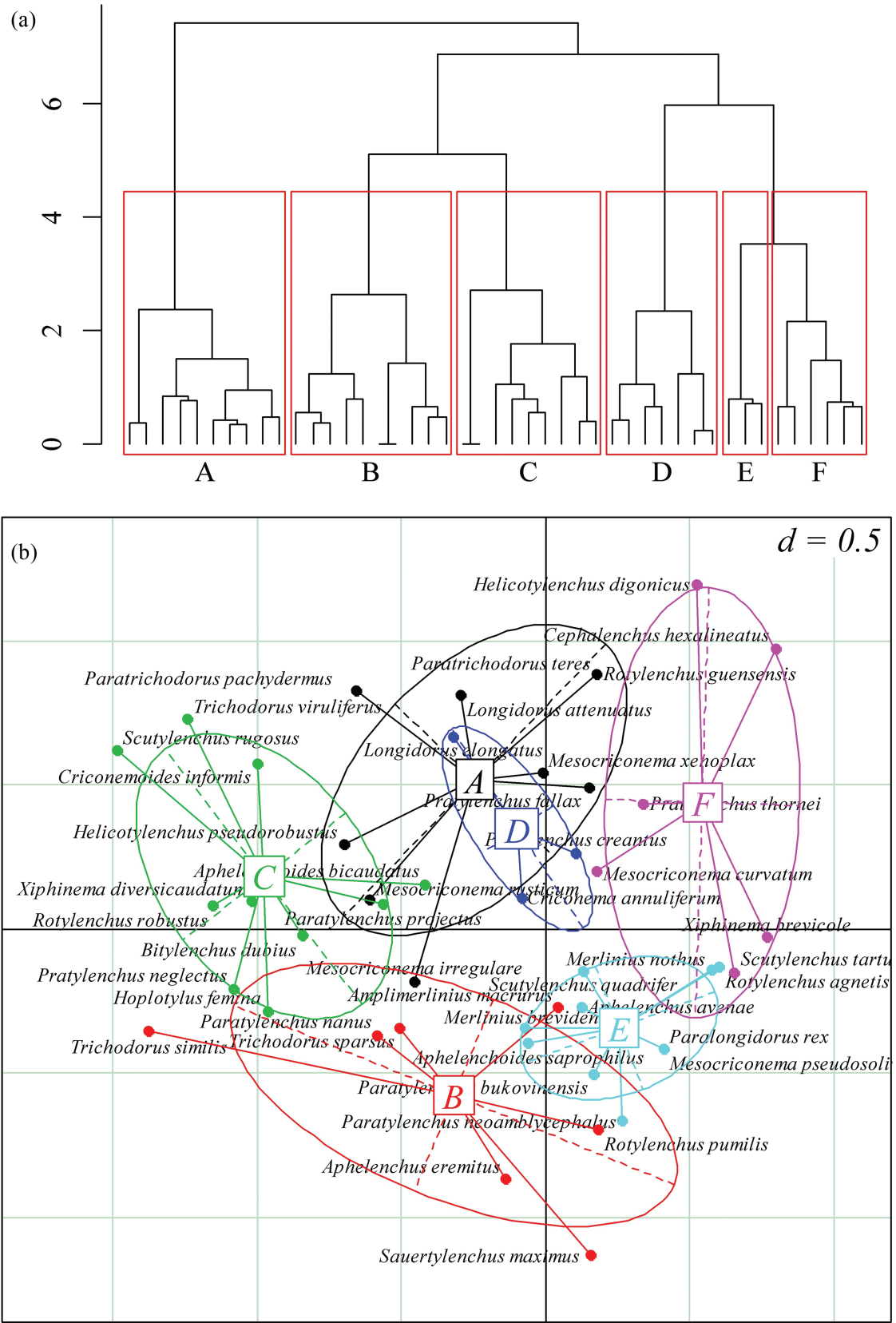

FIGURE 8.3

Cluster analysis and NMDS procedure, where (a) cluster arrangement, Y-scale on the chart is the Euclidian distance between sampling points (presented solution with six clusters representing soil types A, B, C, D, E, and F); (b) the projection of clusters (A, B, C, D, E, and F) in the space of the first two dimensions. (Modified from Stefanovska et al., 2020.) 
Two families Pratylenchus and Helicotylenchus in survey samples represented endoparasite and semi-endoparasite nematodes. Four species of the lesion nematodes Pratylenchus were recovered in both countries. Population densities of P. crenatus and P. neglectus were greater than the estimated damage thresholds (50-100 individuals per $100 \mathrm{~cm}^{3}$ of soil) and can be viewed as the potential pathogen of $M . \times$ giganteus. Pratylenchus spp. are known as very dangerous plant pathogens responsible for lesion disease that rank third place in the world list of the most economically important species (Jones \& Fosu-Nyarko, 2014). This finding for Ukraine and Poland was in agreement with results obtained earlier by Mekete et al. (2011a) in the US.

Spiral nematodes Helicotylenchus were found in densities of 300 individuals per $100 \mathrm{~cm}^{3}$, that is, lower densities than the established threshold value. Hyphal and root feeders were represented by nematodes from four genera: Cylindrolaimus, Rhabditis, Plectus, and Anaplectus that were recovered from samples with population densities up to 25 individuals per $100 \mathrm{~cm}^{3}$ of soil.

The characteristics of PPNs associated with M. x giganteus demonstrated (Mekete et al., 2011b) that economically important nematodes, specifically needle Longidorus elongates (Longidoridae) and root-lesion nematodes Pratylenchus crenatus and Pratylechchus neglectus (Pratylenchidae), share with M. x giganteus other hosts from the same plant family (Gramineae). The fact that all PPNs reported to feed on $M$. x giganteus are pests of corn, sugarcane, or sorghum raises concerns that the production of that crop in the large scale may increase pests not only on M. x giganteus but also on the numbers in existing food and feed crops.

\subsubsection{The Indication of $M . \times$ giganteus Plantation State with Plant-Feeding Nematodes}

M. $\times$ giganteus as a perennial grassland crop generally shows its maximum productivity in the third year of cultivation (Lewandowski et al., 2018). Knowledge based on interaction between PPNs and Miscanthus stands in different age is important to predict biomass productivity during the long-term growing. The PPNs community is determined both by temporal changes and environmental factors (Zhukov et al., 2018). Temporal stages of $M$. $x$ giganteus plantations development in a wide geographical district by PPN species impact the plant damage under representative soil types.

The distribution of nematodes recorded in study in Ukraine and Poland was evaluated by applying the nonmetric multidimensional scaling approach (NMDS) indicated spatial heterogeneity of sampling points and community dynamics (Figure 8.3).

The relationships among the hyphal and root hair feeders, semi-endoparasites, and ectoparasites were suggested as indicators for assessing the state of $M$. $x$ giganteus plantations with different years of cultivation with two aspects which were considered. It was determined (Figure 8.3) that the abundance of hyphal and root hair feeders expanded with increasing of plantation age, whereas the abundance of ectoparasites decreased. The increase in hyphal 
and root hair feeders with increasing age of planting was associated with the reductions in the number of all other trophic groups of parasitic nematodes. Therefore, the increase in hyphal and root hair feeders was the most important marker of the planting age of the M. x giganteus (Stefanovska et al., 2020). This result was in a good agreement with findings of de Goede et al. (1993) which showed an increase in the number of hyphal and root hair feeders in the successional series of crop development.

The research studies carried out for 20 years indicate that intensive involvement of M. x giganteus into biomass systems in conventional agriculture and phytotechnologies stimulates several problems, specifically, worsening the pest problem at other hosts from the same plant family and direct damage of Miscanthus that negatively impacts crop yield. However, considering the perennial nature of $M . \times$ giganteus, its long cultivation may support the increase of biocontrol agents, capable to regulate pest population and keep it under damaging level. It is still not clear to what extent these groups of organisms contribute to yield reduction, and consequently needs for pest management systems that should have been addressed are rather uncertain.

\section{References}

Ben Fradj, N., Rozakis, S., Borzęcka, M., \& Matyka, M. (2020). Miscanthus in the European bio-economy: A network analysis. Industrial Crops and Products, 148, 112281. https://doi.org/10.1016/j.indcrop.2020.112281.

Bernard, G. C., Egnin, M., \& Bonsi, C. (2017). The impact of plant-parasitic nematodes on agriculture and methods of control. In: Shah, M. M., \& Mahamood, M., eds. Nematology Concepts, Characteristics and Control. InTech, London. https://doi. org/10.5772/intechopen.68958.

Blackman, R. L., \& Eastop, V. F. (2000). Aphids on the World's Crop: An Identification Guide (2nd ed.). John Wiley \& Sons Ltd, 476. ISBN: 978-0-471-85191-2.

Bradshaw, J. D., Prasifka, J. R., Steffey, K. L., \& Gray, M. E. (2010). First report of field populations of two potential aphid pests of the bioenergy crop Miscanthus $\times$ giganteus. The Florida Entomologist, 93(1), 135-137. https://doi.org/10.1653/024.093.0123.

Brambila, J. (2009). Steps for the dissection of male Spodoptera moths (Lepidoptera: Noctuidae) and notes on distinguishing S. litura and S. littoralis from native Spodoptera species. USDA-APHIS-PPQ.

Carena, M. J., \& Glogoza, P. (2004). Resistance of maize to the corn leaf aphid: a review. Maydica, 49(4), 241-254. https://doi.org/10.1007/s10681-009-0044-z.

Chiang, H. C. (1973). Bionomics of the Northern and Western corn rootworms. Annual Review of Entomology, 18(1), 47-72. https://doi.org/10.1146/annurev. en.18.010173.000403.

Clark, P. L., Molina-Ochoa, J., Martinelli, S., Skoda, S. R., Isenhour, D. J., Lee, D. J., Krumm, J. T., \& Foster, J. E. (2007). Population variation of the fall armyworm, Spodoptera frugiperda, in the Western Hemisphere. Journal of Insect Science, 7(5), 1-10. https://doi.org/10.1673/031.007.0501. 
Cook, J. H., Beyea, J., \& Keeler, K. H. (1991). Potential impacts of biomass production in the United States on biological diversity. Annual Review of Energy and the Environment, 16(1), 401-431.

Costa-Arbulú, C., Gianoli, E., Gonzáles, W. L., \& Niemeyer, H. M. (2001). Feeding by the aphid Sipha flava produces a reddish spot on leaves of Sorghum halepense: An induced defense? Journal of Chemical Ecology, 27(2), 273-283. https://doi. org/10.1023/A:1005676321251.

Coulette, Q., Couty, A., Lasue, P., Rambaud, C., \& Ameline, A. (2013). Colonization of the biomass energy crop Miscanthus by the three aphid species, Aphis fabae, Myzus persicae, and Rhopalosiphum padi. Journal of Economic Entomology, 106(2), 683-689. https://doi.org/10.1603/EC12147.

de Goede, R. G. M., Verschoor, B. C., \& GeocevA, S. S. (1993). Nematode distribution, trophic structure and biomass in a primary succession of blown-out areas. Fundamental and Applied Nematology, 16(6), 525-538.

De Groote, H., Kimenju, S. C., Munyua, B., Palmas, S., Kassie, M., \& Bruce, A. (2020). Spread and impact of fall armyworm (Spodoptera frugiperda J.E. Smith) in maize production areas of Kenya. Agriculture, Ecosystems and Environment, 292, 106804. https://doi.org/10.1016/j.agee.2019.106804.

Elshout, P. M. F., Zelm, R., Velde, M., Steinmann, Z., \& Huijbregts, M. A. J. (2019). Global relative species loss due to first-generation biofuel production for the transport sector. GCB Bioenergy, 11(6), 763-772. https://doi.org/10.1111/gcbb.12597.

Emery, S. M., Reid, M. L, Bell-Dereske, L, \& Gross, K. L. (2017). Soil mycorrhizal and nematode diversity vary in response to bioenergy crop identity and fertilization. GCB Bioenergy, 9(11), 1644-1656. https://doi.org/10.1111/gcbb.12460.

Gloyna, K., Thieme, T., \& Zellner, M. (2011). Miscanthus, a host for larvae of a European population of Diabrotica v. virgifera. Journal of Applied Entomology, 135(10), 780-785. https://doi.org/10.1111/j.1439-0418.2010.01599.x.

Gołąb-Bogacz, I., Helios, W., Kotecki, A., Kozak, M., \& Jama-Rodzeńska, A. (2020). The influence of three years of supplemental nitrogen on above- and belowground biomass partitioning in a decade-old Miscanthus $x$ giganteus in the Lower Silesian Voivodeship (Poland). Agriculture, 10(10), 473. https://doi.org/10.3390/ agriculture10100473.

Gray, M. E., Sappington, T. W., Miller, N. J., Moeser, J., \& Bohn, M. O. (2009). Adaptation and invasiveness of Western corn rootworm: Intensifying research on a worsening pest. Annual Review of Entomology, 54(1), 303-321. https://doi.org/10.1146/ annurev.ento.54.110807.090434.

Gruss, I., Stefanovska, T., Twardowski, J., Pidlisnyuk, V., \& Shapoval, P. (2019). The ecological risk assessment of soil contamination with Ti and Fe at military sites in Ukraine: Avoidance and reproduction tests with Folsomia candida. Reviews on Environmental Health, 34(3), 303-307. https://doi.org/10.1515/ reveh-2018-0067.

Hentz, M., \& Nuessly, G. (2002). Morphology and biology of Diomus terminatus (Coleoptera: Coccinellidae), a predator of Sipha flava (Homoptera: Aphididae). Florida Enthomologist, 85(1), 276-279. https://doi. org/10.1653/0015-4040(2002)085[0276:mabodt]2.0.co;2.

Hentz, M., \& Nuessly, G. (2004). Development, longevity, and fecundity of Sipha flava (Homoptera: Aphididae) feeding on Sorghum bicolor. Environmental Entomology, 33(3), 546-553. https://doi.org/10.1603/0046-225X-33.3.546. 
Huggett, D. A. J., Leather, S. R., \& Walters, K. F. A. (1999). Suitability of the biomass crop Miscanthus sinensis as a host for the aphids Rhopalosiphum padi (L.) and Rhopalosiphum maidis (F.), and its susceptibility to the plant luteovirus Barley Yellow Dwarf Virus. Agricultural and Forest Entomology, 1(2), 143-149. https://doi. org/10.1046/j.1461-9563.1999.00019.x.

Hull, R. (2002). Matthews' Plant Virology. Academic Press, London.

Hurej, M., \& Twardowski, J. (2009). Phytophagous insects on Miscanthus giganteus (Miscanthus $\times$ giganteus L.). Progress in Plant Protection, 49(3), 1183-1186.

Jarošová, J., Chrpová, J., Šíp, V., \& Kundu, J. K. (2013). A comparative study of the Barley yellow dwarf virus species PAV and PAS: distribution, accumulation and host resistance. Plant Pathology, 62(2), 436-443. https://doi. org/10.1111/j.1365-3059.2012.02644.x.

Jones, M. G. K., \& Fosu-Nyarko, J. (2014). Molecular biology of root lesion nematodes (Pratylenchus spp.) and their interaction with host plants. Annals of Applied Biology, 164(2), 163-181. https://doi.org/10.1111/aab.12105.

Kindler, S. D., \& Dalrymple, R. L. (1999). Relative susceptibility of cereals and pasture grasses to the yellow sugarcane aphid (Homoptera: Aphididae). Journal of Agricultural and Urban Entomology, 16(2), 113-122.

Kosztarab, M., \& Kozár, F. (2012). Scale Insects of Central Europe (Vol. 40). Springer Science \& Business Media, Dordrecht, Netherlands.

Landis, D. A., \& Werling, B. P. (2010). Arthropods and biofuel production systems in North America. Insect Science, 17(3), 220-236. https://doi. org/10.1111/j.1744-7917.2009.01310.x.

Lewandowski, I., Clifton-Brown, J., Kiesel, A., Hastings, A., \& Iqbal, Y. (2018). Miscanthus. In Alexopoulou, E., ed. Perennial Grasses for Bioenergy and Bioproducts: Production, Uses, Sustainability and Markets for Giant Reed, Miscanthus, Switchgrass, Reed Canary Grass and Bamboo. Academic Press, London (pp. 35-55). https://doi.org/10.1016/B978-0-12-812900-5.00002-3.

Macfarlane, S. A. (2003). Molecular determinants of the transmission of plant viruses by nematodes. Molecular Plant Pathology, 4(3), 211-215. https://doi. org/10.1046/j.1364-3703.2003.00164.x.

MacFarlane, S. A., \& Neilson, R. (2009). Testing of transmission of tobraviruses by nematodes. Current Protocols in Microbiology, 12(1), 16B.5.1-16B.5.16. https://doi. org/10.1002/9780471729259.mc16b05s12.

Mekete, T., Gray, M. E., \& Niblack, T. L. (2009). Distribution, morphological description, and molecular characterization of Xiphinema and Longidorous spp. associated with plants, Miscanthus spp. and Panicum virgatum used for biofuels. Global Change Biology Bioenergy, 1, 257-266. https://doi. org/10.1111/j.1757-1707.2009.01020.x.

Mekete, T., Reynolds, K., Lopez-Nicora, H. D., Gray, M. E., \& Niblack, T. L. (2011a). Distribution and diversity of root-lession nematode (Pratylenchus spp.) associated with Miscanthus $\times$ giganteus and Panicum virgatum used for biofuels, and species identification in a multiplex polymerase chain reaction. Nematology, 13(6), 673-686. https://doi.org/10.1163/138855410X538153.

Mekete, T., Reynolds, K., Lopez-Nicora, H. D., Gray, M. E., \& Niblack, T. L. (2011b). Plant-parasitic nematodes are potential pathogens of Miscanthus $\times$ giganteus and Panicum virgatum used for biofuels. Plant Disease, 95(4), 413-418. https://doi. org/10.1094/PDIS-05-10-0335. 
Montezano, D. G., Specht, A., Sosa-Gómez, D. R., Roque-Specht, V. F., Sousa-Silva, J. C., Paula-Moraes, S. V., Peterson, J. A., \& Hunt, T. E. (2018). Host plants of Spodoptera frugiperda (Lepidoptera: Noctuidae) in the Americas. African Entomology, 26(2), 286-300. https://doi.org/10.4001/003.026.0286.

Nuessly, G., \& Hentz, M. (2002). Feeding effects of yellow sugarcane aphid on sugarcane. Journal of the American Society of Sugar Cane Technologists, 22, 126-127.

Pallipparambil, G. R., Cha, G., \& Gray, M. E. (2014). A comparative life-table analysis of Sipha flava (Hemiptera: Aphididae) on two biofuel hosts, Miscanthus x giganteus and Saccharum spp. Journal of Economic Entomology, 107(3), 1069-1075. https://doi. org/10.1603/EC13263.

Prasifka, J. R., Bradshaw, J. D., Meagher, R. L., Nagoshi, R. N., Steffey, K. L., \& Gray, M. E. (2009). Development and feeding of fall armyworm on Miscanthus $\times$ giganteus and switchgrass. Journal of Economic Entomology, 102(6), 2154-2159. https://doi. org/10.1603/029.102.0619.

Reid, W. V., Ali, M. K., \& Field, C. B. (2020). The future of bioenergy. Global Change Biology, 26(1), 274-286. https://doi.org/10.1111/gcb.14883.

Sabluk, V. T., Gryschenko, O. M., \& Stefanovska, T. R. (2014). Control of grub population in plantations of energy willow and giant miscanthus (Miscanthus $\times$ giganteus). Bioenergetyka (Bioenergy), 2, 31-32.

Semere, T., \& Slater, F. M. (2007). Invertebrate populations in miscanthus (Miscanthus $\times$ giganteus) and reed canary-grass (Phalaris arundinacea) fields. Biomassand Bioenergy,31(1),30-39.https://doi.org/10.1016/j.biombioe.2006.07.002.

Spencer, J. L., Hibbard, B. E., Moeser, J., \& Onstad, D. W. (2009). Behaviour and ecology of the western corn rootworm (Diabrotica virgifera virgifera LeConte). Agricultural and Forest Entomology, 11(1), 9-27. https://doi.org/10.1111/j.1461-9563.2008.00399.x.

Stefanovska, T., Chumak, P., Pidlisnyuk, V., Kovalchuk, V., Kava, L., \& Likar, Ya. (2017a). State of the art on adaptability of Miscanthiococcus miscanthi Takaschi (Homoptera, Pseudococcidae) followed by the introduction of Miscanthus $\times$ giganteus to Ukraine. Communications in Applied and Biological Sciences, 82(2), 177-181. ISSN 1379-1176.

Stefanovska, T., Lewis, E., Pidlisnyuk, V., \& Smyrnykh, O. (2015). First record of Clytra laeviuscula Ratzeburg as potential insect pest of energy willow (Salix viminalis L.) in Ukraine. Agriculture (Pol'nohospodárstvo), 61(3), 115-118. https://doi. org/10.1515/agri-2015-0016.

Stefanovska, T., Pidlisnyuk, V., Lewis, E., \& Gorbatenko, A. (2017b). Herbivorous insects diversity at Miscanthus x giganteus in Ukraine. Agriculture, 63(1), 23-32. https://doi.org/10.1515/agri-2017-0003.

Stefanovska, T., Skwiercz, A., Zouhar, M., Pidlisnyuk, V., \& Zhukov, O. (2020). Plantfeeding nematodes associated with Miscanthus $x$ giganteus and their use as potential indicators of the plantations' state. International Journal of Environmental Science and Technology, 1-16. https://doi.org/10.1007/s13762-020-02865-z.

Thomson, L. J., \& Hoffmann, A. A. (2011). Pest management challenges for biofuel crop production. Current Opinion in Environmental Sustainability, 3(1-2), 95-99. https://doi.org/10.1016/j.cosust.2010.11.003.

Toth, S., Szalai, M., Kiss, J., \& Toepfer, S. (2020). Missing temporal effects of soil insecticides and entomopathogenic nematodes in reducing the maize pest Diabrotica virgifera virgifera. Journal of Pest Science, 93(2), 767-781. https://doi.org/10.1007/ s10340-019-01185-7. 
Warner, E., Inman, D., Kunstman, B., Bush, B., Vimmerstedt, L., Peterson, S., Macknick, J., \& Zhang, Y. (2013). Modeling biofuel expansion effects on land use change dynamics. Environmental Research Letters, 8(1), 015003. https://doi. org/10.1088/1748-9326/8/1/015003.

Werling, B. P., Meehan, T. D., Robertson, B. A., Gratton, C., \& Landis, D. A. (2011). Biocontrol potential varies with changes in biofuel-crop plant communities and landscape perenniality. GCB Bioenergy, 3(5), 347-359. https://doi. org/10.1111/j.1757-1707.2011.01092.x.

Wheeler, A. G. (2013). Hyperaspis paludicola Schwarz (Coleoptera: Coccinellidae): Association with Miscanthus mealybug, Miscanthicoccus miscanthi (Takahashi) (Hemiptera: Pseudococcidae), with a review of its distribution. Entomological News, 123(3), 220-224. https://doi.org/10.3157/021.123.0308.

Winkler, B., Mangold, A., von Cossel, M., Clifton-Brown, J., Pogrzeba, M., Lewandowski, I., Iqbal, Y., \& Kiesel, A. (2020). Implementing miscanthus into farming systems: A review of agronomic practices, capital and labour demand. Renewable and Sustainable Energy Reviews, 132, 110053. https://doi.org/10.1016/j. rser.2020.110053.

Yeates, G. W., Bongers, T., De Goede, R. G., Freckman, D. W., \& Georgieva, S. S. (1993). Feeding habits in soil nematode families and genera-an outline for soil ecologists. Journal of Nematology, 25, 315-331.

Yu, E. Y., Gassmann, A. J., \& Sappington, T. W. (2019). Effects of larval density on dispersal and fecundity of western corn rootworm, Diabrotica virgifera virgifera LeConte (Coleoptera: Chrysomelidae). PLoS One, 14(3), e0212696. https://doi. org/10.1371/journal.pone.0212696.

Zhukov, O. V., Kunah, O. M., Dubinina, Y. Y., \& Novikova, V. O. (2018). The role of edaphic, vegetational and spatial factors in structuring soil animal communities in a floodplain forest of the Dnipro river. Folia Oecologica, 45(1), 8-23. https:// doi.org/10.2478/foecol-2018-0002. 